\title{
Green Marketing That Effect the Buying Intention Healthcare Products
}

\author{
Mochamad Soelton* \\ Management Department, Faculty of Economics and Business, Universitas Mercu Buana, Indonesia \\ Facthur Rohman \\ Management Department, Faculty of Economics and Business, Universitas Brawijaya, Indonesia \\ Daru Asih \\ Management Department, Faculty of Economics and Business, Universitas Mercu Buana, Indonesia \\ Eko Tama Putra Saratian \\ Management Department, Faculty of Economics and Business, Universitas Mercu Buana, Indonesia \\ Satriyo Bagus Wiguna \\ Management Department, Faculty of Economics and Business, Universitas Mercu Buana, Indonesia
}

\begin{abstract}
This research aims to find out the effect of country of origin, health consciousness, and green marketing toward the purchase intention of ENTCLEAR Nasal Wash Bottle. The object of this study are the consumers who buy ENTCLEAR Nasal Wash Bottle at drugstore or hospital which cooperates with PT. Kebayoran Pharma South Jakarta. The research method used in this study is a descriptive method. This study was conducted on 125 of respondents using qualitative approach. The technique to gather the data is by using questionaire and Snowball Sampling is used to take the sample. Data Analysis used in this study is Structural Equation Model (SEM) by Smart-PLS 3.2.8. The result of this study shows that Country of Origin, Health Consciousness, and Green Marketing positively and significantly affect the Purchase Intention itself.
\end{abstract}

Keywords: Country Of Origin, Health Consciousness, Green Marketing, Purchase Intention.

DOI: $10.7176 / \mathrm{EJBM} / 12-15-01$

Publication date:May $31^{\text {st }} 2020$

\section{Introduction}

The development industry is now growing rapidly. This turned out to have an impact on environmental issues. Community as a subject that utilizes all natural potential in the business world and has a very important role in shaping a business environment that is friendly to the environment (environmentally friendly). The condition was strengthened with the issue of global warming is becoming a worldwide conversation. Major environmental problems today are illegal logging, water pollution due to industrial waste, air pollution in urban areas, encroachment of protected areas, the declining quality of biodiversity, as well as increased waste plastics (Imaningsih, 2019); (Widayati, 2018); (Chen, 2011).

One of the thing that is at the root of environmental degradation is increasing waste plastics from year- to year. According to the World Bank (2017), the town - city in the world has produced as much as 1.3 billion tons of waste per year, and is expected to grow by 2.2 billion tonnes by 2025 . In 2008 alone, global consumption of plastic products worldwide is estimated to reach 260 million ton.

One of effort to prevent global warming is to switch to using the product Go Green. Go Green is a form of lifestyle change efforts to be more eco-friendly or environmentally friendly. Rohman (2020), Some companies are already sensitive to environmental issues, began to develop a variety of ways to attract consumers who are sensitive to environmental issues. Because the focus of environmental issues into issues

relating to the social, economic, technical or legal system. Environmental problems are localized into global issues, an attitude that assumes the business is a problem, turn into a business as part of the solution to the problem, and the last factor, namely the perception of the environment that focuses more on the relationship dynamics between the business community with the environment (Rohman et al., 2020); (Ramli \& Soelton, 2018); (Peattie in Maharani,2017).

problems are localized into global issues, an attitude that assumes the business is a problem, turn into a business as part of the solution to the problem, and the last factor, namely the perception of the environment that focuses more on the relationship dynamics between the business community with the environment (Peattie in Maharani, 2017)

Go Green concept itself has four 4R principle namely Reduce, Reuse, Recycle and Replace (Anonymous, 2013). (1) Reduce, a process of reducing the use of goods - goods which if discharged untreated back, it will be 
difficult to decompose the waste and soil, wind, or air. (2) Reuse, an activity which is owned reuse products without having to discard or buy new ones. (3) Recycle, recycle the unused product. (4) Replace, using alternative products that are more environmentally friendly than similar products. Basically, 4R through the Go Green campaign is one of them aims to reduce plastic waste that is still frequently used in daily life - today.

One campaign to support the Go Green program can be done to save the earth is the Reuse movement, the act of reusing the product can still be used without having to throw away and buy a new product type. Reuse campaign is one campaign that aims to reduce plastic consumption in Indonesia, since there are many products that are sold using plastic containers. Plastic is an inorganic waste are difficult to decompose and if it continues to accumulate would be a pile of garbage that plague the sights and become pollutants (Rohman et al., 2020), (Setiawan, 2014).

Along with the Go Green campaign being encouraged society, the term called Green Consumerism. According to Smith (1998) in Retnawati (2011) Green Consumerism is defined as "the use of individual consumer preferences to promote less environmentally damaging products and services". The interesting thing about this definition is that green consumerism arises from the awareness and the formation of individual consumer preferences towards product you want to consume. According Retnawati (2011), states that green consumerism has confidence that: 1) there is the problem of a real environment, 2) the problem to be taken seriously and addressed in a way that actively, 3) they felt well informed in the everyday life they, 4) each individual can and should contribute to save the planet from environmental disaster. Green Consumerism is a continuation of the global consumer movement, which began with the awareness of consumers' rights to get a product that is decent, safe and friendly to the environment (environmentally friendly).

One of industry that helped to compete in the business world is the pharmaceutical industry. This is because many consumer demand for various types of drugs and increased consumer awareness of their own health. However, because there are still many pharmaceutical products that use environmentally unfriendly plastic or biodegradable as packaging containers for its products, making products - pharmaceutical product as one that can have an impact on the environment due to plastic waste generated. For the use of packaging impact on the environment, it is clear deviate from green business activity or activities that must be done by each - each industry who are running the business.

Under conditions where the community is aware of the importance of preserving the environment through Go Green, the company is also required to conduct a Green Business in order to create a climate of Green Consumerism. One of the company's strategy of doing green business is to produce a wide range of products using materials that do not damage the environment, known as Green Product. According to (Albino et al., 2009); (Okada \& Mais, 2010) that the green product is designed to reduce excessive use of natural resources during the production process and minimize adverse environmental impacts during the production process.

Associated with the phenomenon already described, one of the pharmaceutical industry are already aware of and implement green business by creating a green product is hyphens Pharma. Hyphens Pharma is a leading pharmaceutical company from Singapore, where the state of Singapore is a country that is advanced, innovative and environmentally friendly in terms of manufacturing. Corresponding image owned by the state of Singapore, hyphens Pharma has a vision "we provide quality of life" with health products are intended for all consumers, in order to have a better quality of life. One of pharmaceutical production by hyphens Pharma is ENTCLEAR Nasal Wash Bottle. ENTCLEAR Nasal Wash Bottle is a medical device product wash bottle-shaped nose that is used to wash the nose.

Asnote that the interest to buy (purchase intention) is a decision that analyze and learn why consumers buy a product in a certain place (Shah et al., 2012). Buying interest (purchase intention) can be interpreted that the desire for someone to buy a product or service that is expected to benefit from the products or services purchased. So here's researchers will study what causes a consumer it would have interest to buy (purchase intention) for a product.

Based on research conducted by Yansritakul (2017), shows that the country of origin (Country of origin) positive and significant impact on buying interest (Purchase Intention) Green Skincare products. Then, research Pratama (2017) demonstrate that the Consciousness of Health (Health Consciousness) positive and significant impact on buying interest (Purchase Intention) Nippon Paint Green Choice products Series. Furthermore, according to a study Nihlah et al (2018), proving that the quality of service (Service Quality) positive and significant impact on buying interest (Purchase intention) Wardah cosmetic products. Then, the research conducted Tirtayani (2017) showed that the Green Marketing positive and significant impact on buying interest (Purchase Intention) environmentally friendly products. Therefore, the researchers first pre-survey to 30 consumers PT. Kebayoran Pharma South Jakarta Branch to analyze the variables that can affect interest in buying (purchase intention) of consumers on product ENTCLEAR Nasal Wash Bottle.

Based on the results above the pre-survey, researchers chose three of the four factors that influence the consumer to be decisive Purchase Intention (Interests Buy). Factor - these are determined based on the indicators of each question pre-survey. The third factor is the Country Of Origin, Health Consciousness, and Green 
Marketing. the writer needs to do research more about the Effect of Country of origin, Health consciousness and Green Marketing on Purchase Intention ENTCLEAR Nasal Wash Bottle.

\section{$>$ Research purposes}

Objective to determine the effect of Country of origin, Health consciousness and Green Marketing on Purchase Intention ENTCLEAR Nasal Wash Bottle.

\section{$>$ Benefits of Research}

The results of this study is expected to increase the insight both in theory and practice as well as a reference and ideas for similar studies. The results of this study can be as a reference for the company to increase sales and instill a new sales strategy with reference to the development of environmentally friendly products based Effect of Country of origin, Health consciousness and Green Marketing on Purchase Intention.

\section{Literature review}

2.1 Country Of Origin

According to Kotler and Keller (2013) The perception of the country of origin is the association and mental confidence triggered by a state. This perception of the country of origin can influence consumer decision-making directly and indirectly. Another opinion said Shirin (2011) that the image of the country of origin is the overall consumer recognition for the country of origin and level of perception of the quality of a particular product.

Country Of Origin measurement basis according to Yassin, Nasser and Osman (2007), namely:

1) Countries where the brand originated is an innovative country in the manufacturing / fabrication

2) Countries where the brand originated is a country that has a level of education and mastery of high technology

3) Countries where the brand originated is a country that has a respectable reputation.

4) Countries where the brand originated is a developed country

5) Countries where the brand originated is a country that has a creative workforce

6) Countries where the brand originated is a country that has a high-quality workforce

7) Countries where the brand originated is the ideal country to visit.

\subsection{Health Consciousness}

According to Kraft and Goodell (1993), Health Conciousness an awareness and concern regarding their awareness and can be motivated by raising or taking care of their health and quality of life as a preventative measure against disease through healthy behaviour and more aware of their health.

According Michaelidou and Hassan (2008), health awareness is a concern and attention for the better and motivated to improve, maintain, maintain the health and quality of life by adopting a healthy lifestyle Furthermore Michaelidou and Hassan stated that there are four dimensions of health awareness namely, awareness in health, concerns are high that food intake affects the health, the healthy and natural foods, and businesses choose healthy foods.

According to Kraft and Goodel (1993) Indicators for measuring health awareness (health consciousness) are as follows:

1) pay attention to the products used

2) self-monitoring health

3) searching health information in the media

4) response procedure if there is a health problem

5) prevention on things that cause disease

6) active in getting people around to being environmentally responsible

\subsection{Green Marketing}

According to Ottman, (2011), Green marketing is the consistency of all the activities that designing services and facilities to the satisfaction of human needs and desires, with no impact on the natural environment. Green products (green product) is a product that does not pollute the environment and does not reduce the resources or that can be recycled.

According to Shabani (2013), green products are products that are usually durable and is not harmful to health. energy-saving green products made to maintain and improve the natural environmental resources and reduce or eliminate the use of hazardous substances, pollutants and waste.

According Pride and Farel in Haryadi (2009) indicators to measure green marketing are:

1) Environmentally friendly (not dangerous to health)

2) Resource efficiency (no excess packaging)

3) Product price comparison 
4) Choosing a price comparable to the quality.

5) direct marketing

6) distance outlet

7) Do not exaggerate attributes or benefits on environmental claims

8) Comparison with other products must be clear and substantial.

\subsection{Purchase Intention}

According to Schiffman \& Kanuk (2010), buying interest is a psychic activity that arises because of the feelings and thoughts of a good or service that is desired. Meanwhile, according to Simamora (2001: 106) in Rangkuti and Sulistiawati (2014) states that the incidence of purchase intent for a product is because it is based in the belief that consumers towards the product which is accompanied with the ability to buy the product. Purchase intent also appears that consumers are interested in so that it can create the motivation that continuously recorded and a strong desire. Purchase intention can be interpreted that the desire for someone to buy a product or service that is expected to benefit from the products or services purchased.

The buying interest may be identified through indicators as follows:

1) Transactional interest, namely the tendency of a person to buy a product.

2) Referential interest, namely the tendency of a person to refer products to others.

3) Preferential interest, the interest of which describes the behaviour of someone who has the main preferences on such products. These preferences can only be replaced if something goes wrong with the product preferences.

4) Explorative interests, namely the interest which describes the behaviour of someone who is always looking for information about a product that interested and looking for information to support the positive properties of the product.

\section{Research methods}

\section{$>$ Research design}

The research design used by the author in this study using quantitative research. According to Noor (2011), a quantitative research methods to test specific theories by examining the relationship between variables. In general, these variables measured by the instrument, so that the resulting data consists of numbers that can be analyzed by statistical procedures.

\section{$>\quad$ Data Collection Instrument}

The instrument used for data collection was a questionnaire. Questionnaires distributed or made directly to the respondents using a Likert scale with the (five) levels.

\section{$>$ Population}

The population in this study is consumers who make purchases of products ENTCLEAR Nasal Wash Bottle, pharmacies or hospitals that cooperate by PT. Kebayoran Pharma South Jakarta branch. This is because researchers do not know the number of the population in detail.

\section{$>$ Samples}

The sample used was snowball sampling technique. according Sugiyono (2014) Snowball sampling is a sampling technique that initially a small amount and then enlarged. Like a snowball rolling that long into a big. Number of samples used in this study were 125 respondents.

\section{$>$ Data analysis}

Analysis and interpretation of data for research aimed to answer research questions in order to reveal certain phenomena. To analyze the data used The Structural Equation Modeling (SEM) of the PLS statistical software version 3.2.8 in the model and the assessment of hypotheses, structural equation modeling. 


\section{Results and discussions}

Table 1.Hasil Convergent Validity Testing (modification)

\begin{tabular}{cccc}
\hline Variables & Indicator & Outer Loading & Information \\
\hline \multirow{5}{*}{ Country Of Origin } & C2 & .638 & Valid \\
& C3 & 0,622 & Valid \\
& C4 & .869 & Valid \\
& C5 & .780 & Valid \\
& C7 & 0.665 & Valid \\
\hline \multirow{5}{*}{ Health Consciousness } & H1 & .601 & Valid \\
& H2 & 0.686 & Valid \\
& H3 & 0.919 & Valid \\
& H5 & 0.727 & Valid \\
& H6 & 0.785 & Valid \\
& G1 & 0,879 & Valid \\
\hline \multirow{5}{*}{ Green Marketing } & G3 & 0.731 & Valid \\
& G4 & .853 & Valid \\
& G5 & .850 & Valid \\
& G6 & 0.763 & Valid \\
& PI1 & .749 & Valid \\
\hline \multirow{5}{*}{ Purchase Intention } & PI2 & .689 & Valid \\
& PI3 & 0.854 & Valid \\
& PI4 & 0.861 & Valid \\
& PI5 & 0.562 & Valid \\
\hline
\end{tabular}

The results of the testing of convergent validity modifications in Table 1, it can be seen that all the indicators have met the convergent validity because it has a value above the loading factor 0:50 and thus all the indicators for measuring the construct of the study was valid. If all indicators have loading factor above 0.5 then the proposed measurement model has the potential for further testing.

Table 2. Results of Testing AVE

\begin{tabular}{lcc}
\hline & Variables & AVE \\
\hline Country Of Origin & .520 \\
Health Consciousness & 0.599 \\
Green Marketing & 0.659 \\
Purchase Intention & 0.565 \\
\hline
\end{tabular}

Table 3. Results of Discriminant Validity Testing (Fornell Lacker Criterium)

\begin{tabular}{lcccc}
\hline & Country Of Origin & Green Marketing & Health Consciousness & Purchase Intention \\
\hline Country Of Origin & 0.721 & & & \\
Green Marketing & .681 & 0,812 & & \\
Health Consciousness & 0.647 & .720 & .774 & 0.752 \\
Purchase Intention & .652 & .671 & 0.672 & \\
\hline
\end{tabular}

From Tables 2 and 3 it can be concluded that the square root of the average variance extracted $(\sqrt{A V E)}$ for each construct is greater than the correlation between constructs one with the other constructs in the model. AVE value based on the above table, it can be concluded that the construct in the model that meet the criteria are estimated discriminant validity.

Table 4. Results of Testing of Composite Reliability and Cronbach's Alpha

\begin{tabular}{lccc}
\hline \multicolumn{1}{c}{ variables } & $\begin{array}{c}\text { composite } \\
\text { Reliability }\end{array}$ & $\begin{array}{c}\text { Cronbach's } \\
\text { Alpha }\end{array}$ & Information \\
\hline Country Of Origin & .842 & 0.764 & Reliable \\
Health Consciousness & .898 & .860 & Reliable \\
Green Marketing & 0,906 & .871 & Reliable \\
Purchase Intention & .864 & 0.803 & Reliable \\
\hline
\end{tabular}

Based on Table 4:14 that the test results of composite reliability and Cronbach's alpha showed a satisfactory value, because all the latent variable has a value of composite reliability and Cronbach's alpha $\geq 0.70$. This means all the latent variables said to be reliable.

\begin{tabular}{cc}
\multicolumn{2}{c}{ Table 5. Value of $\mathrm{R}^{2}$ Endogenous variables } \\
\hline Endogenous variables & R-square \\
\hline Purchase Intention & 0794 \\
\hline
\end{tabular}


Structural model indicates that the model of the variable purchase intention can be said to be moderately strong have a value above 0.67. Model influence of independent latent variables (Country Of Origin, health consciousness and, green marketing) to purchase intention R-square value of 0.794 which can be interpreted that the variability construct purchase intention can be explained by the variability country of origin, health consciousness,and, green marketing amounted to $79.4 \%$, while $20.6 \%$ is explained by other variables outside studied.

\section{Conclusion}

1) Country of origin significant positive effect on consumer purchase intention ENTCLEAR Nasal Wash Bottle. This means the country of origin of a good producer, it will increase the high buying interest from consumers. Otherwise.

2) Health consciousness significant positive effect on consumer purchase intention ENTCLEAR Nasal Wash Bottle. This means that if the nose health awareness is high, then it will be consumers buying interest will increase. Otherwise.

3) Green marketing significant positive effect on consumer purchase intention ENTCLEAR Nasal Wash Bottle. This means that if the concept of a good green marketing, it will increase consumer buying interest. Otherwise.

\section{References}

Abdillah, W., \& Hartono, J. (2015). Alternatif Structural Equation Modeling (SEM) dalam Penelitian Bisnis. Yogyakarta: Andi Offset.

Albino, V., Balice, A., Dangelico, R.M. (2009). Environmental Strategies and Green Product Development: An Overview on Sustainability-Driven Companies. Business Strategy and the Environment, 8(2), 83-96.

Anonymous. (2013). Energy panas bumi. Diunduh dari http:// id. wikepedia.org/wiki/energi panas_bumi. pada 19 November 2015.

Arseculeratne, Dinuk and Rashad Yazdanifard. 2014. How Green Marketing Can Create a Sustainable Competitive Advantage for a Business. International Business Research. 7: 130-137.

Banyte, J., Lina B., \& Agne, G. (2010). Investigation of Green Consumer Profile: A Case of Lithuanian Market of Eco-Friendly Food Products. Economics and Management, pp. 374-383.

Bestari, K. L. (2016). Pengaruh Green Brand Image, Green Advertising dan Harga

Terhadap Keputusan Pembelian. Jurnal Ilmu dan Riset Manajemen, 19.

Chen, Y. S. (2011). Green Organizational Identity: Sources and Consequence. Management Decision, 49(3), 384404.

Delafrooz., Narges., Taleghani, M., \& Nouri, B. (2014). Effect of Green Marketing on Consumer Purchase Behaviour. Diunduh dari http://administrasibisnis.studentjournal.ub.ac.id/ index.php/jab/article/view/ 1705/2085 pada 10 Agustus 2018.

Demirbag, M., Tatoglu, E., Tekinkus, M. and Zaim, S. 2006. An Analysis of The Relationship Between TQM Implementation and Organizational Performance: Evidence from Turkish SMEs. Journal of Manufacturing Technology Management, Vol. 17, No. 6: 829-47.

Dutta-Bergman, M. J. (2004). Complementarity in consumption of news types across traditional and new media. Journal of broadcasting and electronic media, 48(1), 41-20.

F Rohman, YB Abadi, M Soelton, N Prasetyo, ET Saratian. 2020. The Effect of Environmentally Friendly Paper Toward Purchasing Intention. 4th International Conference on Management, Economics and Business (ICMEB 2019). 2020/2 (120-126). atlantis-press.com

Ghozali, I. (2014). Structural Equation Modeling Teori, Konsep dan Aplikasi Dengan Program Partial Least Square. Semarang: Badan Penerbit Universitas Diponegoro.

Gould, S. J. (1988). Public Self-Consciousness and Consumption Behavior. The Journal of Social Psyholohy, $393-$ 400.

Gould, S. J. (1990). Health Consciousness and Health Behavior: The Application of A New Health Consciousness Scale. American Journal of Preventive Medicine, 228-237.

Hair, J., Black, W., Babin, B.J., \& Anderson, R. (2010). Multivariate Data Analysis, Seventh Edition. Pearson Prentice Hall.

Haryadi, R., (2009). Pengaruh Strategi Green Marketing Terhadap Pilihan Konsumen Melalui Pendekatan Marketing Mix Studi Kasus pada The Body Shop Jakarta. [Tesis S2]. Semarang: Universitas Diponegoro.

Haryoso, P. (2010). Pengaruh Kualitas Pelayanan dan Bauran Pemasaran Terhadap Loyalitas Anggota Dengan Kepuasan Anggota Sebagai Variabel Intervening. Journal of Service Marketing, 7(1): h: 66-79.

Hawkins, D., \& Mothershaugh, D.L. (2010). Consumer Behavior Building Marketing Strategy. 11th ed. New York: McGrawHill. Jayanti, R. K., \& Burns, A. C. (1998). The Antecedents of Preventive Health Care Behavior: An Empirical Study. Journal of the Academy of Marketing Science, 6-15. 
Kinra. (2006). The Effect of Country of Origin on Foreign Brand Names in The Indian Market. Marketing Intelligence \& Planning. Vol. 24. No. 1 pp 12-30.

Kotler, P., \& Armstrong, G. (2008). Prinsip-prinsip Pemasaran. Edisi 12. Jilid 1. Penerbit: Erlangga, Jakarta.

Kotler, P., \& Armstrong, G. (2012). Prinsip-prinsip pemasaran. jilid 1. Edisi kedua belas. Di terjemahkan oleh : Sob Sabran. Jakarta: Erlangga.

Kotler, P., \& Keller, K.L. (2013). Manajemen Pemasaran. Edisi ketiga belas. Jilid 1. Jakarta: Erlangga.

Kraft, F. B., \& Goodell, P. W. (1993). Identifying The Health Conscious Consumer. Journal of Health Care Marketing, 18-25.

Laksana, F. (2008). Manajemen Pemasaran: Pendekatan Praktis. Edisi pertama. Cetakan pertam. Yogyakarta: Graha Ilmu.

Listiana, E. (2012). Pengaruh Country of Origin terhadap Perceived Quality dengan Moderasi Etnosentris konsumen. Bandung: Jurnal Administrasi Bisnis FISIP - Unpar, Vol.8, No.1: hal. 21-47.

Listiana., Erna., Elida., Syabanita, S. (2014). Pengaruh Country Of Brand Dan Country Of Origin Terhadap Asosiasi Merek (Studi Pada Pelanggan Produk Elektronik). Media Ekonomi dan Manajemen, Vol. 29, No. 1, Januari 2014, pp.1 - 14.

Maharani, P.N. (2010). Faktor-faktor yang Mempengaruhi Niat Konsumen Dalam Pembelian Produk The Body Shop. Jurnal Ekonomi dan Bisnis, Vol. 4 (1), Maret 2010, hal 1-20 ISSN: 1978-3116. Yogyakarta: Pusat Penelitian dan Pengabdian Masyarakat STIE YKPN Yogyakarta.

Manap, H.A. (2016). Revolusi Manajemen Pemasaran. Edisi kesatu. Penerbit: Mitra Wacana Media, Jakarta.

Michaelidou, N., \& Hassan, L.M. (2008). The Role of Health Consciousness, Food Safety Concern, and Ethical Identity on Attitudes and Intentions Towards Organic Food. International Journal of Consumer Studies, Vol. 32 No. 2 pp. 163-70.

Mutaminah \& Siyatimah. (2012). Model Pengembangan Green Business untuk Peningkatan Kinerja Keuangan dan Kinerja Pasar. Proceeding Forum Manajemen Indonesia (FMI), Yogyakarta, 2012.

Moorman, C., \& Matulich, E. (1993). A Model of Consumers' Preventive Health Behaviors: The Role of Health Motivation and Health Ability. Journal of Consumer Research, 208-228.

Noor. J. (2011). Metodologi Penelitian: Skripsi, Tesis, Disertasi, \& Karya Ilmiah. Jakarta: Prenada Media Group.

Okada, E.M. \& Mais, E.L. (2010). Framing the Green Alternative for Environmentally Conscious Consumers, Sustainability Accounting. Management and Policy Journal, 1 (2), 222-234.

Ottman, J. (2011). The New Rule Of Green Marketing. UK, Europe: Greenleaf. Ravida, V., \& Saino. (2015). Pengaruh Country of Origin terhadap Minat Beli dengan Perceived Quality sebagai Variabel Intervening (Studi Pada Pengunjung Artomorro Selluler Kota Madiun). Surabaya: Pendidikan Tata Niaga Universitas Negeri Surabaya.

Pramono, R. (2012). Analisis Pengaruh Harga Kompetitif, Desain Produk, dan Layanan Purna Jual Terhadap Minat Beli Konsumen Sepeda Motor Yamaha di Kota Semarang. Jurnal Jurusan Manajemen Fakultas Ekonomika dan Bisnis, Universitas Diponegoro. Volume 1, Nomor 1, Tahun 2012, Halaman 1-9.

Ramli, Y., \& Soelton, M. (2018). Implementing Innovation Management on Market Attractiveness and Unique Resources to Enhance Business Performance on Organic Fertilizer Industries in Indonesia. Academy of Strategic Management Journal. 17 (April), 1-12

Retnawati, B. (2011). Peningkatan Nilai Merek Asli Indonesia dengan Green Branding. Jurnal Dinamika Sosial Ekonomi, Vol 7, 1-9, Edisi Mei 2011.

Shaputra, R.K. (2013). Penerapan Green Marketing Pada Bisnis Produk Kosmetik. Alumni Universitas Ma Chung Malang.

Rosyidi, Syaiko. 2009. Analisis Pengaruh Brand, Country of Design dan Country of Assembly Pada Persepsi Kualitas dan Niat Beli. Jurnal Potensio. Volume 11, No $1: 10-33$.

Saydan, R. (2013). Relationship between Country of Origin Image and Brand Equity: An Empirical Evidence in England Market. International Journal of Business and Social Science. Yuzuncu Yil University. Vol. 4 No. 3; March 2013.

Setiawan, B. (2018). Pengelompokan Limbah Berdasarkan Jenis Senyawa (Komposisinya). Diunduh dari http://ilmulingkungan.com/pengelompokan-limbah-berdasarkan-jenissenyawa-komposisnya/ pada 8 Agustus 2018.

Shabani, Nazanin., Mahboobeh Ashoori, Moh. Taghinejad, Hamed Beyrami, and Marjan N. Fekri. 2013. The Study of Green Consumers' Characteristics and Available Green Sectors in The Market. International Research Journal of Applied and Basic Science. Science Explorer Publication, 4(7): 1880-1883.

Shah, S.S. Hussain, J. Aziz, A.R. Jaffari, S.Waris, W.Ejaz, M.Fatima and S.K. Sherazi. (2012). The Impact of Brands on Consumer Purchase Intentions. Asian Journal of Bussiness Management. Vol.4, No.2, pp: 105110.

Shaputra, R.K. (2013). Penerapan Green Marketing Pada Bisnis Produk Kosmetik. Jurnal JIBEKA, Vol 7 (3), Agustus $2013: 47-53$. 
Shirin, K., \& Kambiz, H.H. (2011). The Effect of the Country-of-Origin Image, Product Knowledge and Product Involvement on Consumer Purchase Decisions. Science and Research Branch, Islamic Azad University, Tehran, Iran. August 2011, Vol. 10, No. 8, 601-615.

Situmorang, J.R. (2011). Pemasaran hijau yang semakin menjadi kebutuhan dalam bisnis. Jurnal Administrasi Bisnis, Volume 7, No. 2, 131-142.

Sugiyono. (2014). Metode Penelitian Bisnis (Pendekatan Kuantitatif, Kualitatif, dan R\&D). Bandung: Alfabeta. Sumarwan, Ujang, A.G dkk. (2012). Riset Pemasaran dan Konsumen, Seri 2. Bogor: PT Penerbit IPB Press.

Sumarwan, U. (2011). Pemasaran Strategik: Perspektif Value-Based Marketing \& Pengukuran Kinerja. Bandung: IPB.

Sunyoto, D. (2013). PERILAKU KONSUMEN (Panduan Riset Sederhana Untuk Mengenali Konsumen). Yogyakarta: CAPS (Center of Academic Publishing Service).

Tiwari, S., Tripathi, D.M., Srivastava, U., \& Yadav, P.K. (2011). Green Marketing-Emerging Dimensions. Journal of Business Excellence, 2(1), 18-23.

Tjiptono, F., \& Chandra, G. (2012). Pemasaran Strategik Edisi 2. Yogyakarta: C.V ANDI OFFSET.

Wu, S. I., and Chen, Y. J. 2014. The Impact of Green Marketing and Perceived Innovation on Purchase Intention for Green Products. International Journal of Marketing Studies. 6 (5), pp: 1918-719.

Yassin, N.M., Nasser, M., \& Osman, M. (2007). Does Image of Country of Origin Matter To Brand Equity?. Journal Of Product and Brand Management. Vol. 6, pp: 38-48. 